\title{
On the Teaching Reform of Financial Accounting Practice Course in Higher Vocational Colleges
}

\author{
Yao Xiong, Yang Zhang \\ Jiangxi Biotech Vocational College, Nanchang, 330220, China
}

Keywords: financial accounting; higher vocational college; teaching reform

\begin{abstract}
In higher vocational colleges, Financial Accounting practice teaching has been a key discipline, and a kind of teaching method to guide students to apply theory knowledge related to Financial Accounting with the purpose of cultivating operational ability. The basic contents of Accounting Practice teaching include single simulation, curriculum simulation, comprehensive simulation, accounting computerization simulation and so on. The teaching aim of practical training course is not only to train the operational ability of students, but also to train students into high-quality talents.
\end{abstract}

\section{Introduction}

The goal of higher vocational education is to train application-oriented talents who are able to adapt to the society. Whether can grasp the practical teaching steps or not will be related to the result of talents training. This paper briefly analyzes the present situation of Financial Accounting Practice teaching in higher vocational colleges and puts forward some measures to improve it.

\section{Background and Practical Significance of Financial Accounting Practice Course in Higher Vocational Colleges}

\subsection{Course Background}

As we all know, at present, most higher vocational colleges in our country have Accounting major. Courses of Accounting major still take a simulated and simulated teaching mode. Teaching materials are related to simulation training. Teaching methods only stay in the stage of theory teaching and simulation teaching, ranging from theoretical teaching to simulation teaching. Teachers and students' actual operation of contact and study can only be realized through simulation and most students can not even recognize the original bill, which is not conducive to the cultivation of students' habits of independent operation. Students lack the corresponding sense of responsibility and self-confidence, let alone the ability to analyze and solve problems. This will lead to their superficial understanding of professional skills and fail to adapt to the needs of society after graduation.

\subsection{Realistic Meaning}

As a teacher engaging in teaching accounting, I deeply realized that the teaching reform of this course is especially important for higher vocational colleges. For this reason, I reviewed my teaching experience and am well aware of the necessity of exploring and researching this teaching reform, hoping to arouse the attention and resonance of the whole society, to be helpful to the teaching of professional skills in higher vocational colleges, and to get the approval and support of the relevant departments of the state. Let us work together to cultivate high-level professional and skilled personnel who are able to meet the needs of modern social and economic development, to meet the overall needs of enterprises and society, and to meet the needs of national economic development. 


\section{Present Status of Financial Accounting Practice Teaching}

\subsection{Insufficient Accounting Experience of Professional Teachers}

At present, most teachers of Accounting major in higher vocational colleges are engaged in teaching after graduation, and generally lack practical experience in Accounting work. Therefore, skills teaching is always limited to books. For a long time in the past, our country paid attention to the exploration and research of university teachers' science, but neglected the support and cultivation of all kinds of professional skills, and the rapid updating of Accounting system, thus, teachers' original practical experience can not keep up with the changes. On the other hand, most higher vocational colleges do not have a corresponding system to integrate teachers' participation in social practice into teaching management plans, and there are no corresponding arrangements and guarantees in terms of time, organization and funding. Therefore, it is inevitable to deviate from practice in teaching activities, which can not guarantee the teaching quality of Financial Accounting Practice in higher vocational colleges, and it is difficult for teachers' professional skills to meet the needs of teaching.

\subsection{Unsatisfactory Practice Teaching Environment}

Accounting Practice is an operational and practical course. At present, most vocational colleges have been equipped with accounting simulation training room to provide students with accounting practice training. But as far as the configuration of the laboratory is concerned, it is far from meeting the requirements of simulation. Moreover, experimental funds is in a shortage, the hardware and software of the laboratory lags behind the actual situation, and there is no complete accounting simulation data system, all of which can not guarantee the demand of experimental training. Professional teaching has always followed the higher education, that is, the scientific research type of education, teaching mode that students have generally accepted. Generally speaking, by this method, teachers always teach and students try to memory. Even the operation of some professional skills is also simulated and there is no great difference between theoretical learning and practical learning. Moreover, under the guidance of teachers, students basically do not pass through careful thinking and discrimination, but blindly follow and remember what was taught, and finally hand in the "correct" economic and business accounting vouchers and relevant account books after teacher's guidance. In the process of learning and operation, students do not really feel the enterprise or the company's environment and work atmosphere, nor can they really experience the hardships of work and the identification of real raw materials.

\subsection{A Lack of Hardware for Practical Teaching}

At present in most higher vocational colleges, Accounting Practical materials are obsolete and need improvement. The professional teaching of Accounting is based on theories and simulation and the basic equipment and facilities of teaching are set up according to the simulation teaching mode in the past which basically can not meet the requirements of Integrated Simulation of Accounting Practice. In recent years, new implemented Accounting system and standards result in accounting policy, accounting estimate, accounting changes and more new services or standards be integrated into Accounting practice. The contents have been greatly improved, but the reform and innovation of this course still need equipment and perfection of hardware facilities. This requires a lot of land resources and facilities resources, namely the need of national policy and funding support, in order to meet the urgent needs of the current professional skills teaching of Accounting. Professional materials have always been authored or co authored by experts and scholars. These experts and scholars have very deep attainments in the academic, but because of this, many of them are not engaged in the system of professional work, or have other practical experience. Or, because they have been away from professional skill jobs a long time, when compiling teaching materials of Accounting, some contents are far away from the actual work, or they do not meet the actual requirements, some even worked in reverse order. The existence of this phenomenon also influence the training of high-level professional skills. 


\subsection{Single Practice Teaching Method}

Teachers in higher vocational colleges basically have no or few opportunities to conduct social practice learning. Relatively speaking, there are very few teachers with social practical operation experience. Even a small number of teachers with practical experience have been re-recruited by schools in recent years. They are experts, scholars with only teaching experience, or senior technicians with professional skills but no teaching experience. The current Accounting Practice, compared with the real business, lack an actual operation of real business transactions. Students can only learn all kinds of accounting vouchers through practical teaching materials in practical training center, and complete the filling of vouchers, the registration of account books and the compilation of statements by teachers' explanation and guidance. Because of the monotony and inflexibility of practical teaching, students' interest and enthusiasm in practical teaching are affected.

\section{Reform Measures of Financial Accounting Practice Teaching}

\subsection{Increase the Amount of Practical Hours in Teaching}

In higher vocational education of developed countries, practical teaching takes a large proportion and pays more attention to the professional function of curriculum. In Germany, for example, two thirds of the time spent in enterprise training. The curriculum design focuses on students' practice and experimental training, and alternately carries out theoretical and practical teaching. The training goal of higher vocational education is high quality skilled talents, so we should increase the proportion of practical teaching hours, increase the contents of hands-on training, so as to help students adapt to the environment quickly and be proficient in post work after graduation. The author thinks that the teaching hours of Financial Accounting Practice in higher vocational education should account for more than $50 \%$ of the total class hours, which is beneficial to the training of students' Accounting Practice skills.

\subsection{Implement Modular Teaching}

A new practice teaching system can be constructed according to the work process. Practice teaching projects are in accordance with the common positions of accounting profession and implement modular teaching. The modular curriculum design in accordance with accounting positions, including cashier module, accounting module, inventory accounting module, fixed assets accounting module, wage accounting module, financial accounting module, general ledger report the accounting module. Each module includes the post responsibility and accounting skills required and the corresponding simulation operations. The accounting skills of each post are completed in the form of scattered learning first, and finally at the stage of comprehensive simulation of Accounting Practice (that is, the accounting module of general ledger statements). Students need to integrate the accounting skills mastered in the study of the former modules and strengthen the consolidation. In this way, the comprehensive simulation of Accounting will really become a practical exercise of the actual work. Because students' initiative and enthusiasm are brought into full play, and accounting posts and skills are taken as the main content, it will definitely be adapt to the training goal of Accounting major in higher vocational education.This kind of practical teaching of post Accounting makes it possible for students to meet the requirements of the post quickly no matter what Accounting position they are engaged in after they are employed, realizing the seamless docking with employment.

\subsection{Attach Importance to Practice Teaching Materials Construction}

At present, there are many Practical teaching materials in Financial colleges and higher vocational colleges about Financial Accounting major, but few of them are applicable. Reasonable selection and organization of a set of appropriate professional teaching materials is the first problem to be solved in order to improve teaching quality and train qualified personnel. According to the principle of combination of purchasing and self-editing, we can choose excellent teaching materials published in public or take authoritative textbooks as guidance, compile them timely and often 
revise them to organize appropriate teaching materials system. Its remarkable characteristic is to establish a dynamic and applicable teaching material system, to keep up with the changes of relevant laws, regulations, norms and systems, and to keep the structure and content of teaching materials fresh and practical all the time, so as to achieve a higher teaching purpose.

\subsection{Strengthen the Construction of Teaching Staff in Practical Teaching}

The quality and ability of teachers directly affect the quality of practical teaching and ultimately determine the quality of Accounting personnel training. The construction of teachers in Accounting Practice teaching should be carried out from the following aspects:

\subsection{1 pay attention to the cultivation of "double qualified" teachers}

Higher vocational colleges should meet the needs of the reform of personnel training mode in higher vocational education and pay attention to the construction of "double qualified" teachers structure. We also should to increase the proportion of teachers with enterprise work experience among professional teachers, the proportion of "double qualified" teachers in professional basic courses and professional courses should not be less than $50 \%$. Therefore, on one hand, Accounting teachers will be selected and sent to large enterprises, listed companies and Accounting firms in a planned way to carry out internships and training in order to accumulate practical work experience and improve their practical teaching ability. On the other hand, to encourage Accounting teachers to take examinations for technical positions and professional qualifications such as Accountants and Certified Public Accountants while completing their teaching plans, we should allow them to hold the corresponding position in relevant industry associations and accounting firms without affecting their teaching work, so that they know more about the actual situation in the actual work.

\subsection{2 hire technical personnel to enrich the teaching staff of practical teaching}

We are supposed to hires Accountant Profession Managers with the rich practice experience from the industry, enterprise and the society as the part-time teachers and make them to take some teaching tasks of the curriculum with the technical and strong practical characteristics which will improve the structure of teacher as well as make the college adapt to the requirements of professional change.

\section{5 improve practical teaching method}

The traditional teacher-centered teaching mode and the inherited single practical teaching mode can no longer meet the needs of the training goal of Accounting talents. In order to establish the teaching concepts of "students-centered and teachers-dominated", we need to actively explore various new teaching methods based on the cultivation of students' quality, innovation, practice and application ability, and to introduce modern educational technology, carry on the practice teaching in all directions, and improve the practice teaching quality continuously.

\subsection{Strengthen the construction of practice base in and outside the college to ensure that students have more practical opportunities}

Higher vocational colleges increase more experimental investment to establish Accounting simulation training rooms with strong simulation which can simulate all aspects of the future work process, work environment, job functions. And according to the needs of the society and the development, we need to constantly update teaching equipment, Accounting experiment and experimental data. In the construction of practice base outside school, we should sign the cooperation agreement with enterprises, make clear the rights and obligations of both sides and the management responsibility during students' practice period, and maintain a long-term cooperation so that the practice base outside can be stable and effective.

\section{7 implement parallel practice of manual accounting and computerized accounting}

Higher vocational colleges should introduce the real Accounting data of enterprises, and let students analyze and understand the real Accounting data. Under the guidance of teachers, students 
should firstly carry out manual accounting. When finishing the manual accounting at the same time, they need to complete the operation of the total Accounting through computers, then compare the manual accounting process with the computerized accounting process, and verifies each other. By connecting manual Accounting with computerized Accounting, students not only consolidate the knowledge of manual accounting, but also understand and master the whole process of computerized accounting and the implementation situation of each stage. Besides, they will feel the influence which the modern science and technology advancement has brought to the accounting discipline.

\section{Conclusion}

The reform of Accounting Practice teaching is a systematic project, which is quite urgent. Higher vocational colleges should combine the social reality and the actual situation to find out the breakthrough points and laws step by step to strive to put this important work into practice, and create conditions for continuously improving teaching quality and training the practical accounting professionals.

\section{References}

[1] Some Opinions of the Ministry of Education on Improving the Teaching Quality of Higher Vocational Education in an All-round Way. The Ministry of Education [2006] 16.

[2] Lu Jinping. On the Practical Teaching of Financial Accounting in Higher Vocational Colleges [J]. China Economist, 2007.9. 